\title{
Effect of Light on the Gonad and Body Weight in the Crested Bunting (Melophus lathami)
}

\author{
P. D. Tewary and Vinod Kumar \\ Department of Zoology, Banaras Hindu University, \\ Varanasi-221 005, India
}

(Received October 27, 1982)

\begin{abstract}
Groups of photosensitive male Crested Buntings were exposed to short days (8L : 16D), long days (15L:9D), and constant illumination (LL) for 60, 85 and 105 days, respectively. Periodic laparotomies during the treatments indicated that the testes were stimulated in the birds in $15 \mathrm{~L}: 9 \mathrm{D}$ and LL, but not in $8 \mathrm{~L}: 16 \mathrm{D}$. Also, testicular growth in LL was followed by rapid involution after 75 days, indicating 'onset' of the photorefractoriness. However, except a slight decline $(P<0.05)$ in weight of the birds in LL at the end (day 105), there was no significant difference between initial and periodically observed weights in any of the treatments. The results suggest that the Crested Bunting is a photosensitive bird which might be using daily photoperiods in control of its seasonal responses in nature, and has a post-reproductive refractory period in its annual gonadal cycle.
\end{abstract}

Less is known about the importance of daylength in control of reproduction and associated events in the low-latitude seasonal breeders. However, under experimental conditions it has been shown that some tropical/subtropical avian species will show a testicular response to increased daylengths. ${ }^{1-5)}$ This paper reports the results of experiments designed on another subtropical local avian migrant, the Crested Bunting (Melophus lathami), to investigate if it uses daylength in control of seasonal responses, and if the photorefractoriness is demonstrable under laboratory conditions. We selected Melophus lathami for photoperiodic studies because it is a seasonal breeder and, under wild conditions, its gonadal cycle appears to follow the annual solar cycle. ${ }^{6)}$ This species is a seasonal local migrant, and is found locally and patchily throughout the lower Himalayas, up to about 1,500 m from Kashmir to E. Assam, Mount Abu, Rajasthan and central India south to about Satara, East to Bihar. ${ }^{6)}$

\section{MATERIALS AND METHODS}

Adult male buntings were caught locally, at Varanasi, India (latitude $25^{\circ} 18^{\prime} \mathrm{N}$, longitude $83^{\circ} 01^{\prime} \mathrm{E}$ ), during the late November when they were with completely regressed gonads (combined testicular weight, CTW $=5-8 \mathrm{mg}$ ). They were acclimatized to the laboratory conditions for two weeks, and kept under short day conditions (8L : 16D) for 60 days so that they would become photosensitive. Laparotomy of the birds at 30 days intervals during the pretreatment indicated that they had maintained minimal testes size $(\mathrm{CTW}=5-8 \mathrm{mg}$ ); body weight (ca. $21 \mathrm{~g}$ ) had also been unaffected.

Two groups ( $n=6$ each) of buntings were then exposed to long days (15L : 9D) 
and constant illumination (LL) for 85 and 105 days, respectively; a group $(n=4)$ was continued under the same $8 \mathrm{~L}: 16 \mathrm{D}$ for another 60 days. Light-tight boxes containing these bird groups, housed in wire-net cages, were illuminated by 10 -watt fluorescent tubes providing light at an intensity of about 400 lux at the perch level. Food and water were given ad libitum. The birds in all treatments were weighed and laparotomized periodically (see Table 1); their testicular growth was estimated in situ by visual comparison with a standard series of fixed tests of known weights. The error inherent in this method is about $\pm 20 \%$. The data were analyzed statistically by student's ' $t$ ' test.

\section{RESULTS AND DISCUSSION}

Testes were stimulated in the birds in $\mathrm{LL}$ and $15 \mathrm{~L}: 9 \mathrm{D}$, but not in $8 \mathrm{~L}: 16 \mathrm{D}$. In LL, testis growth was maximal on day $45(P<0.001)$ and persisted until day 75 . Birds in this treatment on day 105 had involuted testes (CTW=ca. $8 \mathrm{mg}$ ), a size associated with inactive state of spermatogenesis, indicating 'onset' of the photorefractoriness. In 15L : 9D, also, testicular growth was evident on day $30(P<0.001)$, attained maximal on day 60 , and persisted until day 85. A photorefractoriness condition in these birds, however, could be expected if they had been for some more days under the treatment. Short days, in contrast, could not stimulate the gonads in a duration of about 4 months (including pretreatment period). Further, except a slight reduction $(P<0.05)$ in the weight of buntings under LL at the end (Table 1), there was no apparent difference between the initial and periodically observed weights during all the experiments.

The present experiments were attempted to characterize the effects of photoperiods on gonadal and body weight responses, and responsiveness to subsequent photostimulation in the male Melophus lathami. The results suggest that the wild

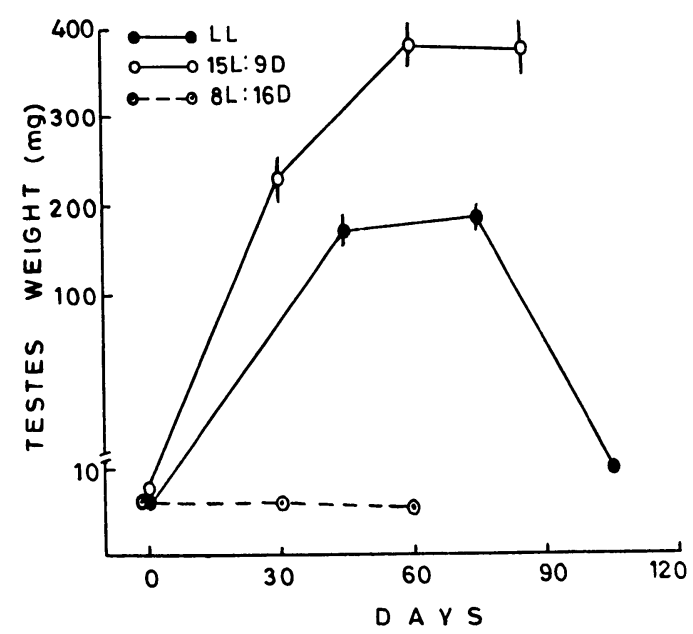

Fig. 1 Gonadal responses of adult Melophus lathami to LL, 15L :9D, and $8 \mathrm{~L}: 16 \mathrm{D}$. Each point represents the mean for a group. Vertical bar shows standard error if it extends limit of the point symbol. 
Table 1 Changes in body weight of Melophus lathami exposed to constant light (LL), long days (15L : 9D), and short days (8L : 16D) (Values are mean S.E.; Figures in parentheses: number of individuals).

\begin{tabular}{rrrrrrr}
\hline \multicolumn{2}{c}{ TREATMENT } \\
\hline \multicolumn{2}{c}{ Constant light (LL) } & \multicolumn{2}{c}{ Long days (15L : 9D) } & \multicolumn{2}{c}{ Short days (8L : 16D) } \\
\hline Days & Body weight $(\mathrm{g})$ & Days & Body weight $(\mathrm{g})$ & Days & Body weight (g) \\
\hline 0 & $22.00 \pm 0.96(6)$ & 0 & $21.16 \pm 0.94(6)$ & 0 & $22.50 \pm 0.62(4)$ \\
45 & $22.50 \pm 0.67(6)$ & 30 & $22.83 \pm 0.87(6)$ & 30 & $21.50 \pm 0.85(4)$ \\
75 & $22.75 \pm 0.85(4)$ & 60 & $22.20 \pm 0.58(5)$ & 60 & $22.00 \pm 1.00(3)$ \\
105 & $17.75 \pm 1.18^{*}(4)$ & 85 & $23.50 \pm 0.95(4)$ & - & - \\
\hline
\end{tabular}

* $P<0.05$ compared with initials.

Crested Buntings might be using increasing daylengths of spring and summer in control of their gonadal responses. Further, Fig. 1 shows that the photoperiodically induced testicular response of $M$. lathami under $15 \mathrm{~L}: 9 \mathrm{D}$ and $\mathrm{LL}$ is very much similar to the responses reported for other birds. ${ }^{2-5},{ }^{7-9}$ ) More so, gonadal involution in Crested Buntings on the face of constant illumination confirms the presence of a photorefractory period in annual reproductive cycle of this bunting. However, unlike the Japanese Quails which exhibit spontaneous gonadal growth after 12 weeks of hatching when maintained under $8 \mathrm{~L}: 16 \mathrm{D},{ }^{10)}$ testes of Crested Buntings were not photostimulated by short daylengths exposed for 16 weeks.

Our data, nonetheless, are inconsistent with some of the observations available for few other Indian birds. Ploceus philippinus (Indian Weaver bird) has no photorefractory in its gonadal cycle, ${ }^{11)}$ though uses long photoperiods to induce gonadal recrudescence. ${ }^{1)}$ Subtropical Munias, on the other hand, behave to artificial photoperiods in a very interesting manner. While Munia malacca malacca (Blackheaded Munia) responds to long as well as short daylengths, ${ }^{12)}$ Lonchura punctulata (Spotted Munia) responds neither to LL nor to long daylengths but shows full testicular growth under the photoperiods less than $6 \mathrm{hr}$ per day. ${ }^{13)}$ Melophus lathami appears to be a species which uses long days in triggering its reproductive activities. Since the body weight remains almost unaffected during any of the treatments (Table 1), clearly neither the photoperiods nor the endogenous gonadal steroids appear to have any influence on the weight in this species. This is not surprising since Crested Buntings are not true migrants. A similar situation has been found in the common Indian Rosefinch (Carpodacus erythrinus), a short distance migrant. ${ }^{14)}$ (It is worthmentioning here that the magnitude of fattening, in general, is directly proportional to the lengths of migratory flights involved. $\left.{ }^{15)}\right)$ However, a slight reduction $(P<0.05)$ in the weight of birds under LL at the end (day 105), when they are showing gonadal refractoriness, may suggest that there may be a metabolic refractory period too, coinciding with gonadal refractory period, in their annual cycles.

Financial support from the University Grants Commission of India is acknowledged.

\section{REFERENCES}

1) Thapliyal, J. P., and P. D. Tewary. 1964. Effect of light on the pituitary, gonad and 
plumage pigmentation in the Avadavat, Estrilda amandava and Baya Weaver, Ploceus philip pinus. Proc. Zool. Soc. London 142: 67-71.

2) Tewary, P. D., and V. Kumar. 1982. Photoperiodic responses of a subtropical migratory finch, the Blackheaded bunting (Emberiza melanocephala). Condor 84: 168-171.

3) Kumar, V., and P. D. Tewary. 1982a. Photoperiodic testicular response and photorefractoriness in common Indian Rosefinch. Environ. Control in Biol. 20: 39-42.

4) Kumar, V., and P. D. Tewary. 1982b. Response to experimental photoperiods by a migratory bunting, Emberiza melanocephala. Ibis (accepted).

5) Tewary, P. D., V. Kumar, and B. N. Prasad. 1982. Influence of photoperiod in subtropical migratory finch, the common Indian Rosefinch Carpodacus erythrinus. Ibis (in press).

6) Ali. S., and S. D. Ripley. 1974. "Handbook of the birds of India and Pakistan" Vol. 10, Oxford University Press, Bombay, London, New York.

7) Farner, D. S., and B. K. Follett. 1966. Light and other environmental factors affecting avian reproduction. J. Anim. Sci. 25: 90-115.

8) Lofts, B., and R. K. Murton. 1968. Photoperiodic and physiological adaptations regulating avian breeding cycles and their ecological significance. J. Zool. 155: 327-394.

9) Hamner, W. M. 1968. The Photorefractory period of the House Finch. Ecology 49: 211227.

10) Oishr, T. 1978. Effect of short days in the photoperiodic testicular response of Japanese quail. Environ. Control in Biol. 16: 35-40.

11) Thapliyal, J. P., and R. N. Saxena. 1964a. Absence of refractory period in common Weaver bird, Ploceus philippinus. Condor 66: 199-208.

12) Thapliyal, J. P., and R. N. Saxena. 1964b. Gonadal development of the male Blackheaded munia under constant nine-hour (short) days. J. Exp. Zool. 156: 153-156.

13) Chandola, A., J. Pavnaskar, and J. P. Thapliyal. 1975. Scoto/photoperiodic responses of a subtropical finch (Spotted munia) in relation to seasonal breeding cycle. J. Interdiscipl. C.ycle Res. 6: 189-202.

14) Kumar, V. 1981. "Photoperiodic response of some migratory birds" $\mathrm{Ph}$. D. Dissertation, Banaras Hindu University, Varanasi (India).

15) Farner, D. S., and R. A. Lewis. 1971. Photoperiodism and reproductive cycles in birds. In "Photophysiology" (Ed. by Giese, A. C.) Vol. 6 325-370, Academic Press, New York and London.

\title{
〈和文抄録〉
}

\section{ホオジロの一種 Crested Bunting にみられる生殖腺と体重に対する光の影響}

\author{
P.D. テワリー・ヴィノド クマール \\ バナラスヒンドゥ大学動物学科
}

ホオジロの一種 Crested Bunting を短日 8L : 16D, 長日 15L : 9D, 常明 LL の光環境のもとに, 60 日, 85 日, 105 日間飼育して生殖腺と体重の変化について観察した結果, 精巣の発育は $15 \mathrm{~L}, \mathrm{LL} の$ 個体にみられたが，8L の個体にはみられなかった。しかし，LL の環境では75 日後に急速に光不感応 現象が現れて精巣の退縮がみられた. しかるに, 体重の変化は実験の開始時と終了時においてほとんど みられなかったことから, このトリは自然環境において季節的光環境に反応し, 繁殖期の後に光不感応 期をもつ種類であることが判明した。

(文責：加藤 勝) 